\title{
THE ANTI-CATARACT EFFECT OF COENZYME Q10 IN RABBITS
}

\author{
Original Article
}

\author{
BAHA'A A. ABDUL-HUSSEIN, AHMED SALIM MAHMOOD
}

Head of Dept. of Pharmacology, College of Veterinary Medicine, University of Al-Qadissiya, Al-Qadissiya Iraq, PhD Student in Pharmacology, College of Medicine, Al-Mustansiriyah University, Baghdad-Iraq

Email: ahmedsalimpharmacist@hotmail.com

Received: 24 Feb 2016 Revised and Accepted: 09 Jan 2017

\begin{abstract}
Objective: cataract is the opacity of the lens which progressively impairs the light transmission to the retina and finally prevents the vision, these opacity result from the oxidative process in the eye. The study aimed to prevent opacity of the lens by using Coenzyme Q10 as eye drops.
\end{abstract}

Methods: Sodium selenite $0.01 \mathrm{w} / \mathrm{v}$ injected intravitreal to the rabbit's eye to induce the disease, a group of rabbits were receive Coenzyme Q10 eye drop, and another group received distilled water, pre and post induction, cataract maturity was measured to evaluate the opacity deterioration.

Results: the group of rabbits that received distilled water after induction of cataract, the opacity occurred within $48-72 \mathrm{~h}$ and the mean score of opacity reached to $(4 \pm 0.00)$, while Coenzyme Q10 treated group the degree of opacity was $(1.5 \pm 0.02)$, and there was a highly significant difference $(p<0.01)$.

Conclusion: Coenzyme q10 has an antioxidant activity when use as eye drops and this effect enable Coenzyme Q10 to prevent the opacity which is the major cause of cataract due to oxidative stress.

Keywords: Cataractogenesis, Oxidative stress, Coenzyme Q10

(C) 2016 The Authors. Published by Innovare Academic Sciences Pvt Ltd. This is an open access article under the CC BY license (http://creativecommons.org/licenses/by/4. 0/) DOI: http://dx.doi.org/10.22159/ijpps.2017v9i3.11391

\section{INTRODUCTION}

Cataract is an illness that affects the eye; it causes opacity of the lens which progressively impairs the light transmission to the retina and finally prevents the vision. Oxidative damage to lens constituents, including nucleic acids, proteins, and lipids, is considered to be a primary factor in aging-related cataract $[1,2]$.

Normally our bodies counteracts this oxidative damage by regular antioxidant defense pathway, however, with age, activated species of oxygen accumulate while the antioxidant defence system gradually decrease. This accumulation of oxidant products results cross-linking and aggregation of proteins with increasing in molecular weight that can scatter light. Consequently, opacification of the lens occur resulting in blocking of light transmission to the retina then blindness [3, 4].

In medicine, surgical removal of the lens considers the best therapy for treatment of the cataract. But, the cost of the cataract surgery considers the major problem for patients living in poverty countries [5]. Early diagnosis of cataract can delays the onset of the disease and reduces the option of surgery by as much as $50 \%$ [6].

Many compounds with antioxidant properties have been evaluated to prevent the cataract. $\mathrm{N}$-acetylcarnosine is considered one of the powerful antioxidant which was developed as an eye drop dosage form. This compound act by delivering the L-carnosine, which act by neutralize the damage of the lens that cause by oxidative stress [7].

Coenzyme Q10 (Cq10) or Ubiquinone, which is the natural vitamin, play a vital role in the electron transport system of mitochondria and consider as the main component of oxidative phosphorylation process that produces the ATP which is the main source of energy in the cell. Besides that, it has an effect on gene expression. Current evidence indicated that $\mathrm{Cq} 10$ has powerful antioxidant properties [8, 10]. Hence the rational design for this research is to assess the efficacy of Cq10 eye drop in the prevention of cataract.

\section{MATERIALS AND METHODS}

\section{Chemicals}

Water soluble Cq10 was purchased from Swan Health Product, USA. Benzylkonium chloride is a gift from Sammara Drug Industry, Iraq. Sterile sodium chloride solution was utilised which made in Adwic pharmaceutical Co., Egypt. Ketamine solution also utilised which produced by Hikma Pharmaceuticals Plc, Jordan.

\section{Animals}

A group of 12 adult rabbits (Oryctologus cuniculus), aged about one year with a range of body weight of $(1.5-2 \mathrm{~kg})$ were purchased from the college of veterinary medicine/University of Baghdad. Animals were kept on fresh trefoil diet, water at libitum, room temperature $\left(25-27^{\circ} \mathrm{C}\right)$ and light/dark cycle of $12 / 12 \mathrm{~h}$.

\section{Preparation of coenzyme Q10 eye drops}

Coenzyme Q10 eye drops are prepared by dissolving $300 \mathrm{mg}$ of water soluble Cq10 (Swanson Health Products, USA) in sufficient amount of sterile distilled water to achieve $0.3 \% \mathrm{w} / \mathrm{v}$ of $\mathrm{Cq} 10$ solution. Benzalkonium chloride is also used as a preservative in a concentration of $0.001 \%$. Finally, the solution was sterilised utilizing a $0.2 \mu \mathrm{m}$ pore size filters and kept in a sterile dropper to be used as an eye drop solution $[10,11]$.

\section{Therapeutic groups}

Therapeutic groups were 2 groups; Cq10 and distilled water (control) group. Each group included 6 rabbits. Cq10 group were administered 2 drops of Cq10 eye drop topically 3 times/day to the right eye for five days prior to induction of cataract (i.e. prophylactic use) and continued thereafter for further $21 \mathrm{~d}$ after the cataract being induced (i.e. therapeutic use), whereas left eyes were received the distilled water (the same volume, frequency and duration). The control group was given distilled water only.

\section{Induction of cataract}

The rabbits were anesthetized by intramuscular injection of $0.5 \mathrm{ml}$ of ( 50 $\mathrm{mg} / \mathrm{ml}$ ) ketamine. Induction of disease was done by inserting the needle of (gauge 30, $12.7 \mathrm{~mm}$ ), ( $4 \mathrm{~mm}$ behind the limbus in sclera measured by caliper) to intravitreal injection of $0.1 \mathrm{ml}$ from $0.01 \% \mathrm{w} / \mathrm{v}$ of sodium selenite solution in right eye; it was single injection [12].

After the injection, the rabbits were monitored for caractogenesis which begun after one hour and when opacity progression observed [13]. Monitoring was done by slit-lamp examination to detect of cataract type $[14,15]$. 


\section{Ophthalmoscopic examination and opacity grading}

The scoring of lens opacity from grade zero to grade 4 (by using ophthalmoscope grading criteria), was doing according to the classification of [16]. The eye examinations were daily carried out in a dark room with a direct ophthalmoscopes method to evaluate cataract maturity and the papillary response to light [17]. The retinal red reflex was visualised through the dilated pupil (installation of tropicamide $0.5 \%$ and phenylephrine $10 \%$ to obtain maximum dilatation); the opacities partially obscured the red reflex [18-20].

The obtained ophthalmoscopic scoring was found to be similar to those obtained with slit-lamp scoring for the same rabbits [21].

\section{Statistical analysis}

All data were expressed as mean $( \pm S E M)$. Paired and unpaired $t$ tests were used accordingly for assessing the effectiveness of employed therapy between groups.

\section{RESULTS}

The type of cataract that was obtained in the present study was Posterior subcapsular (PSC) according to slit-lamp detection and according to opacity classification system, see fig. (1). In the right eyes of control group a complete opacity (mature cataract) was observed after 48 to $72 \mathrm{~h}$ after induction of the disease (fig. 2).

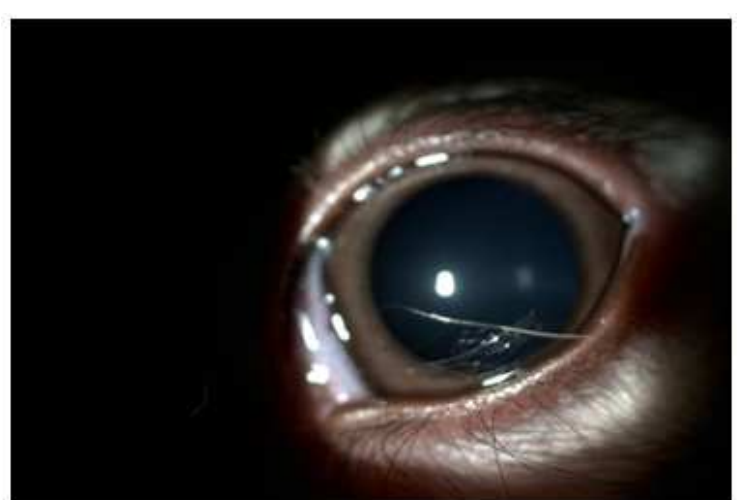

(A)

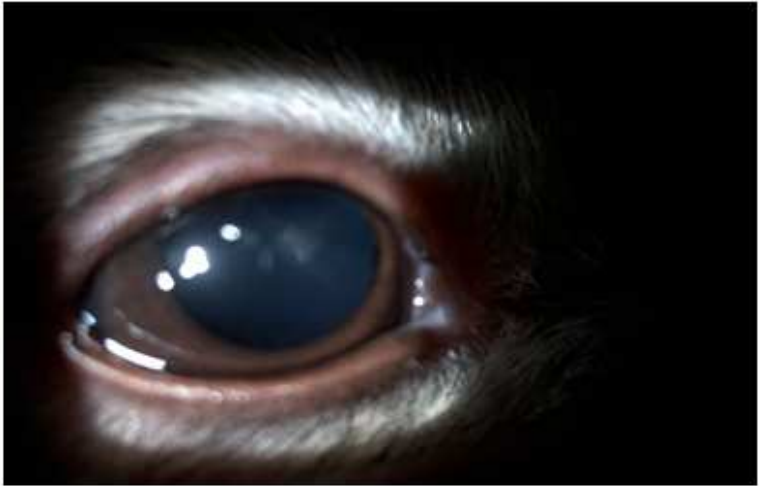

(B)

Fig. 1: Slit lamp photograph of left normal eye (A) and right cataractous eye (B) (Posterior subcapsular opacity)

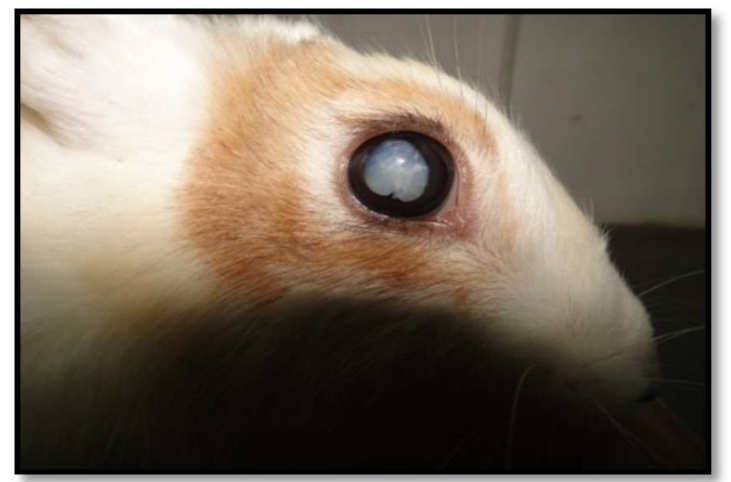

Fig. 2: Mature cataract with clear opacity in the eye of control group animal

\section{Distilled water (control) group}

Prior the induction of cataract the lenses of 6 included rabbits right eye was intact and transparent pre-instillation, and post-installation of distilled water and the mean score of opacity (mean \pm SEM) was $(0 \pm 0.00)$ for $5 \mathrm{~d}$. After cataract being induced and installation of distilled water was continued the mean score was $(2.8 \pm 1.7)$ at $1^{\text {st }}$ day post-induction and $(4 \pm 0.00)$ at each of $7^{\text {th }}, 14^{\text {th }}$ and $21^{\text {st }}$ day of trial period, and there was a highly significant $(\mathrm{P}<0.01)$ difference in comparing to right eyes pre-induction (fig. 3).

All included rabbits right eye had intact light reflex after installation of distilled water for 5days. But post induction of cataract all the right eyes had no light reflex during the trial period.

Regarding light reflex, there was highly significant $(p<0.01)$ differences post induction during the trial period.

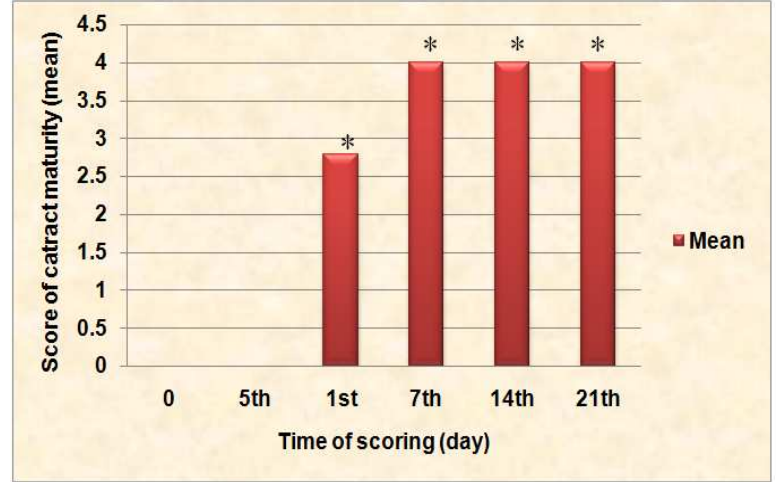

Fig. 3: Effect of distilled water on mean score of cataract maturity in eye rabbits' lenses $(n=6)$ during pre-induction $(0$ and $5^{\text {th }}$ day) and Post-induction period ( $\left.21 \mathrm{~d}\right)$, The values are represented as $($ mean \pm SEM), $S E M=$ standard error of mean, $* *=$ high significant difference $(\mathrm{p}<0.01)$ compared to corresponding pre-induction mean score of cataract maturity

\section{Cq10 group}

Prior the induction of cataract the lenses of 6 included rabbits' right eye was intact and transparent pre and post installation of Cq10 eye drops and the mean score of opacity (mean \pm SEM) was $(0 \pm 0.00)$ for 5 d. After cataract being induced and installation of Cq10 was continued the mean score was $(0.1 \pm 0.03)$ at the $7^{\text {th }}$ day, and in comparing with right eyes pre-induction there was a highly significant $(\mathrm{P}<0.01)$ difference, at the $14^{\text {th }}$ day there was a highly significant $(\mathrm{P}<0.01)$ difference, the mean score was $(1.5 \pm 0.05)$, at the $21^{\text {st }}$ also there was highly significant difference $(\mathrm{P}<0.01)$ and the

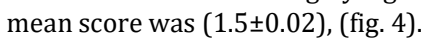


Table 1: Effect of Cq10 (0.3\%) eye drops on prevention of cataract maturity in right eyes of rabbits (n=6) compared with distilled water

\begin{tabular}{|c|c|c|c|c|c|c|}
\hline \multirow[t]{3}{*}{ Groups } & \multicolumn{6}{|c|}{ Score of cataract maturity (mean \pm SEM) } \\
\hline & \multicolumn{2}{|c|}{ Pre-induction of cataract (Day) } & \multicolumn{3}{|c|}{ Post-induction of cataract (Day) } & \multirow[b]{2}{*}{$21^{\text {st }}$} \\
\hline & $\mathbf{0}$ & 5 & $\mathbf{1}^{\text {st }}$ & $7^{\text {th }}$ & 14th & \\
\hline Distilled Water & $0 \pm 0.00$ & $0 \pm 0.00$ & $2.8 \pm 1.7$ & $4 \pm 0.00$ & $4 \pm 0.00$ & $4 \pm 0.00$ \\
\hline $\mathrm{Cq} 10$ & $0 \pm 0.00 \mathrm{~N} \circ$ & $0 \pm 0.00^{\mathrm{N}} \circ$ & $0.4 \pm 0.0$ & $0.1 \pm 0.03 * *$ & $1.5 \pm 0.05^{* *}$ & $1.5 \pm 0.02^{* *}$ \\
\hline
\end{tabular}

Value are represented as mean \pm SEM, $0=$ Baseline (Pre-treatment), SEM=standard error No (normal eye), $* *=$ highly significant difference (P $\leq$ 0.01), Cq10= Coenzyme Q10.

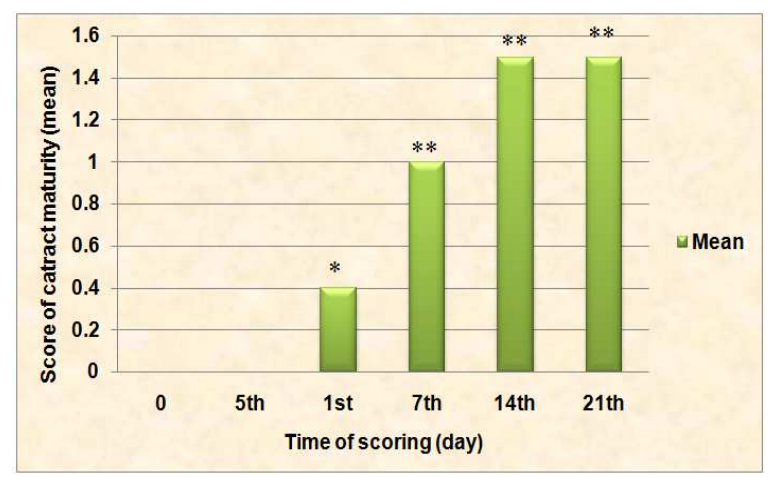

Fig. 4: Effect of Cq10 on mean score of cataract maturity in eye rabbits' lenses $(n=6)$ during pre-induction $\left(0\right.$ and $5^{\text {th }}$ day) and Post-induction period (21 d), Values are represented as (mean \pm SEM) ${ }^{*}=$ Significant difference $(0.01 \leq$ p<0.05) compared to corresponding pre-induction mean score of cataract maturity, ${ }^{* *}=$ high significant difference $(\mathbf{p}<0.01)$ compared to corresponding pre-induction mean score of cataract maturity

The Cq10 (0.3\%) eye drop was more efficient in cataract prevention effect than distilled water during the trial period, (table 1).

All included rabbits right eye had intact light reflex after installation of Cq10 for 5days. Post-induction of cataract also all right eyes had light reflex until the $7^{\text {th }}$ day, but there was no response at day $14^{\text {th }}$ and $21^{\text {st }}$ post induction.

Regarding light reflex, there was a significant difference $0.01 \leq$ $\mathrm{p}<0.05)$ during the trial period. However there was significant $(0.01 \leq p<0.05)$ difference regarding comparison results of light reflex, of $\mathrm{Cq} 10$ with those of distilled water post induction.

\section{DISCUSSION}

Selenite-induced cataract has received considerable attention and was worked upon as a model system for oxidative stress-induced cataract [22]. Selenite causes increasing lipid peroxidation and oxidation of sulfhydryl groups and damage of membranes of lens fibres. This mechanism resembles age-related cataract [23]. These processes lead to protein aggregation and result in a decrease the water soluble proteins followed by opacification of the lens [24, 25]. Chung et al. 2001, Chung et al. (2002) suggest that nitric oxide had an important role in the development of selenite-induced cataracts [26]. Many researchers have been demonstrating the effectiveness of high doses of antioxidant supplements (vitamins C and E) in attenuating (but not preventing) the oxidative stressinduced cataractogenesis $[27,28]$. Cq10 is a synthesis in the human body and involved in the cell function. It has a powerful antioxidant effect. An in vitro study has been observed the efficacy of Cq10 in prevention the effects of light-induced oxidative stress and apoptosis in human lens epithelial cells in a cell culture model [29]. Coenzyme q10 has an antioxidant activity against oxygen species which responsible for the oxidative stress, and when Cq10 used topically as eye drop, it was able to prevent the oxidative stress in the eye, so the expected mechanism to reduce opacity, is the antioxidant activity of $\mathrm{Cq} 10$ that prevent aggregation of lens proteins and enhancing to dissociation of cross-links between aggregated proteins to the normal state, and prevents progression of the opacity [30].

\section{CONCLUSION}

Coenzyme Q10 has an antioxidant activity when uses as eye drops and this effect enable Coenzyme Q10 to prevent the opacity of the lens which is the major cause of cataract due to oxidative stress.

\section{CONFLICT OF INTERESTS}

Declared none

\section{REFERENCES}

1. Spector A. Oxidative stress-induced cataract: mechanism of action. FASEB J 1995; 9:1173-82.

2. Huang L, Estrada R, Yappert MC, Borchman D. Oxidationinduced changes in human lens epithelial cells.1. Phospholipids. Free Radical Biol Med 2006;41:1425-32.

3. Horwitz J. Lens alpha-crystallin: function and structure. Eye (Lond) 1999;13:403-8.

4. Wu H, Yu Y, David L, Ho Y, F Lou M. Glutaredoxin 2 (Grx2) gene deletion induces early onset of age-dependent cataracts in mice. J Biol Chem 2014;289:36125-39.

5. Marianne Shahsuvaryan. The management of cataract: where we are? EC Ophthalmol 2016;33:304-8.

6. Kupfer $\mathrm{C}$ Bowman lectures. The conquest of cataract: a global challenge. Trans Ophthalmol Soc UK 1985;104:1-10.

7. Boldyrev AA. The antioxidative properties of carnosine, a natural histidine-containing dipeptide. Biochem Int 1987; 15:1105-13.

8. Groneberg DA, Kindermann B, Althammer M, Klapper M, Vormann J, Littarru GP, et al. Coenzyme Q10 affects the expression of genes involved in cell signaling, metabolism and transport in human CaCo-2 cells. Int J Biochem Cell Biol 2005;37:1208-18.

9. A W Linnane H. Eastwood: cellular redox poise modulation; the role of coenzyme Q10, gene and metabolic regulation. Mitochondrion 2004;4:779-89.

10. Rita Mencucci, Eleonora Favuzza, Carlotta Boccalini, Andrea Lapucci, Roberta Felici, Francesco Resta, et al. CoQ10Containing eye drops prevent UVB-induced corneal cell damage and increase cornea wound healing by preserving mitochondrial function. Invest Ophthalmol Visual Sci 2014;55:7266-71.

11. Allen LV, Popovich NG, Ansel HC. Ansel's pharmaceutical dossage forms and drug delivery systems. $8^{\text {th }}$ ed. Lippincott Williams and Wilkins: Philadelphia; 2005.

12. Cotlier E. Physiology of the lens. In: Moses RA, Hart WM. Alder's physiology of the clinical eye application. 9 $9^{\text {th }}$ ed. Mosby Company: St. Louis; 1995.

13. Samuel J, Ziegler JR, Datlies MB. Pathogenesis of cataracts. In: Thomas M, Aaberg SR, Richard L, Mark B, Dharam V. Duane's Foundations of Clinical Ophthalmology: Lippincott Williams and Wilkins; 2003.

14. Kanski J. Kanski clinical ophthalmology a systemic approach. $6^{\text {th }}$ ed. Lippincott's: Philadelphia and Sant Louis; 2007.

15. American academy of ophthalmology; 2010. Available from: www.aao.com. [Last accessed on 20 Jan 2016]

16. Chylack LT, Wolfe JK, Singer DM, Leske MC, Bullimore MA, Bailey IL, et al. The lens opacities classification system III. The longitudinal study of cataract study group. Arch Ophthalmol 1993;111:831-6. 
17. Datiles MB, Magno BV. Cataract: clinical types. In: Thomas M, Aaberg SR, Richard L, Mark B, Dharam V. Duane's Foundations of Clinical Ophthalmology. Lippincott Williams and Wilkins: Philadelphia; 2003.

18. Macdonald M. The examination of the eye. In: Munro J, Edwards C. Macleod's Clinical Examination. 10th. ed. Churchill Livingstone: Edinburgh; 2000.

19. Paton D, Hyman B, Justice J. Introduction to ophthalmoscopy. $4^{\text {th }}$ ed. Upjohn: Michigan; 1996.

20. Ahuja M. Ophthalmology Handbook. $1^{\text {st }}$ ed. India Binding House: Delhi; 2003.

21. Mehra V, Minassian DC. A rapid method of grading cataract in epidemiological studies and eye surveys. $\mathrm{Br} \mathrm{J}$ Ophthalmol 1998;72:801-3.

22. Chitra V, Lakshamib KS, Sharmaa S, Patidara A, Rajeshb T. Lisinopril attenuates selenite-induced experimental cataract development: an in vitro study. Int J Pharm Pharm Sci 2009;1:17-23.

23. Ito $\mathrm{Y}$, Nabekura $\mathrm{T}$, Takeda $\mathrm{M}$, Nakao $\mathrm{M}$, Terao $\mathrm{M}$, Hori $\mathrm{R}$, et al. Nitric oxide participates in cataract development in selenitetreated rats. Curr Eye Res 2001;22:215-20.

24. Ohkawa H, Ohishi N, Yagi K. Assay of lipid peroxide in animal tissue by thiobarbituric acid reaction. Anal Biochem 1997;95:351-7.
25. Shearer TR, Hong M, Fukiage K, Azuma M. Selenite nuclear cataract: a review of the model. Mol Vision 1997;3:8:651-722.

26. Chung LK, Ching KC, Hsu WM. Nitric oxide levels in the aqueous humor in cataract patients. J Cataract Refractive Surg 2002;28:507-12.

27. MARS JA. High-dose antioxidant supplementation and cataract risk. Nutr Rev 2004;62:28-32.

28. Li Yan, Liu Ya-Zhen, Shi Jing-Ming, Jia Song-Bai. Alpha-lipoic acid protects the lens from H202-induced cataract by inhibiting. Asian Pacific J Trop Med 2013;6:558-1.

29. Kernt M, Hirneiss C, Neubauer SA, Ulbig MW, Kampik A. Coenzyme Q10 prevents human lens epithelial cells from light-induced apoptotic cell death by reducing oxidative stress and stabilizing $\mathrm{BAXBcl}-2$ ratio. Acta Ophthalmol 2010;88:e78-e86.

30. Crane Frederick L. Biochemical functions of coenzyme Q10. J Am College Nutr 2001;20:591-8.

\section{How to cite this article}

- Baha'a A Abdul-Hussein, Ahmed Salem Mahmood. The anticataract effect of coenzyme Q10 in rabbits. Int J Pharm Pharm Sci 2017;9(3):13-16. 